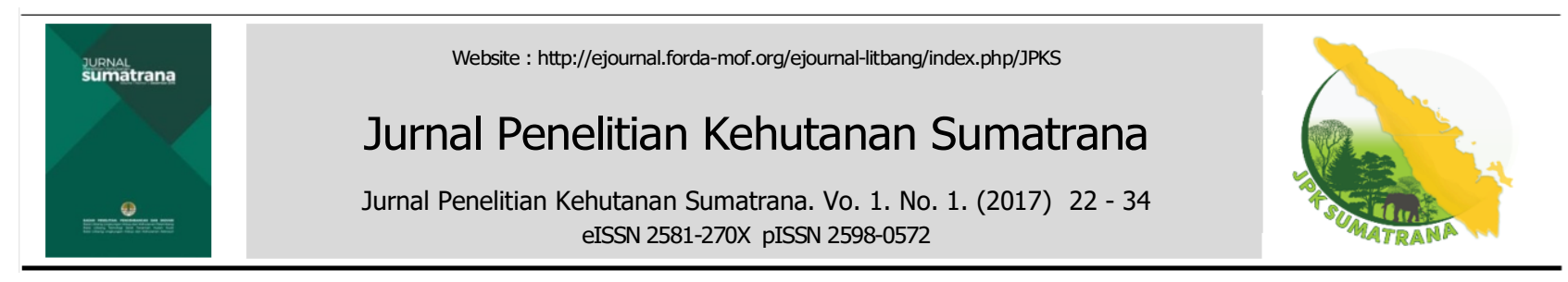

\title{
Korelasi genetik Pertumbuhan dan Produksi Getah Pada Uji Keturunan Pinus merkusii Di KPH Banyumas Barat
}

\section{(Genetic Correlation of Growth and Resin Yield in Progeny Test Pinus merkusii Jungh. et de Vriese at KPH Banyumas Barat)}

\author{
Imam Muslimin ${ }^{1 *}$ \\ ${ }^{1}$ Balai Penelitian dan Pengembangan Lingkungan Hidup dan Kehutanan Palembang \\ Jl. Kol. H. Burlian Km. 6,5 Punti Kayu Palembang Tlp. 0711-414864 \\ *E-mail: imam_balittaman@yahoo.co.id \\ Article History: \\ Received 7 February 2017; Received in revised from 21 March 2017 \\ Accepted 7 Agustus 2017; Avaible online since 30 Sept 2017
}

\begin{abstract}
ABSTRAK
Penelitian ini bertujuan untuk mengetahui korelasi genetik pertumbuhan (tinggi dan diameter) terhadap produksi getah tanaman uji keturunan Pinus merkusii. Penelitian dilakukan pada uji keturunan half-sib P. merkusii produksi getah umur 4 tahun, menggunakan Incomplete Block dengan Row Column Design sistem sub galur (Sulawesi 1, KBS Sumedang 1, Sulawesi 2 dan Jatim 2). Korelasi genetik antara tinggi dan diameter terhadap produksi getah pada sub galur KBS Sumedang bernilai negatif sehingga seleksi lebih lanjut hanya ditujukan untuk produksi getah saja. Sedangkan korelasi genetik pada sub galur Sulawesi 2, Sulawesi 1 dan Jatim 2 bernilai positif sehingga seleksi lebih lanjut ditujukan untuk produksi kayu dan getah.
\end{abstract}

Kata kunci: Korelasi genetik, pertumbuhan, Pinus merkusii, sub galur, uji keturunan

\begin{abstract}
The research was aimed to assess the correlation between genetic of growth (diameter and height) and resin yield of progeny test Pinus merkusii. The study was conducted on half-sib

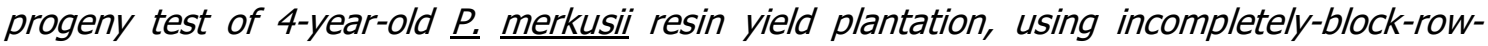
column design by sub-line system of the following seed sources (Sulawesi 1, SSO Sumedang 1, Sulawesi 2 and Jatim 2). Genetic correlation between resin yield and tree height and diameter of sub-line SSO Sumedang were negative, therefore the further selection only addressed for resin production. On the other hand, the genetic correlation for sub-line Sulawesi 1, Sulawesi 2 and Jatim 2 were positive and further selection would be designed for resin and wood production.
\end{abstract}

Keywords: Genetic correlation, growth, Pinus merkusii, progeny test, sub-line

\section{PENDAHULUAN}

Pinus merkusii Jungh. et de Vriese merupakan salah satu jenis tanaman asli Indonesia yang menghasilkan hasil hutan bukan kayu berupa getah yang melalui proses destilasi menghasilkan gondorukem dan terpentin. Dalam perkembangannya, pengelolaan getah menjadi prioritas dengan pertimbangan: (1) mempunyai derivat yang beragam sebagai bahan baku di banyak industri, (2) harga jual semakin tinggi 
(gondorukem mencapai US\$ 1.600-1.700 per ton (Antara, 2010) dan terpentin US\$ 2.200 per ton (Hasniawati, 2010) sementara produsennya terbatas (China, Brazil dan Indonesia (Antara, 2010)), (3) membuka lapangan pekerjaan penyadapan, (4) pemanfaatan hasil hutan bukan kayu sangat membantu pemerintah mengatasi isu pemanasan global.

Produksi getah tusam Perhutani 5 tahun terakhir (2005-2009) rata-rata adalah 81.801 ton/tahun, sedangkan kapasitas pabrik gondorukem dan terpentin (PGT) sebesar 110.595 ton/tahun, sehingga setiap tahun terjadi defisit sekitar 28.794 ton/tahun (Saepudin, 2010). Salah satu upaya yang ditempuh adalah melalui program pemuliaan dengan melakukan pembangunan uji keturunan $P$. merkusii untuk produksi getah pada tahun 2007 di $\mathrm{KPH}$ Banyumas Barat. Pemilihan materi pohon induk yang digunakan berdasarkan kriteria utama produksi getah tinggi (Fakultas Kehutanan UGM, 2006). Langkah ini ditempuh karena beberapa penelitian membuktikan bahwa produksi getah pinus dikendalikan kuat oleh faktor genetik dengan nilai heritabilitas yang tinggi (Leksono, 1994; Prasetia, 2008; Pswarayi et al., 1996; Shimizu \& Spir, 1999; Roberds et al., 2003), sehingga peningkatan produksi getah melalui tindakan pemuliaan (seleksi genetik) merupakan pilihan yang efektif.

Selain menghasilkan produk hasil hutan bukan kayu berupa getah, tanaman pinus juga menghasilkan produk kayu yang dipanen pada akhir daur. Harga ekspor kayu olahan pinus pada tahun 2012 sebesar US\$ 400/m ${ }^{3}$ $50 \%$ lebih rendah apabila dibandingkan dengan harga kayu olahan Jati (US\$ $1.000 / \mathrm{M}^{3}$ ). Namun nilai ini merupakan harga kayu olahan yang tertinggi bila dibandingkan dengan akasia, sengon, karet, balsa, eucalyptus dan sungkai (Kementerian Keuangan, 2012). Potensi produksi tanaman pinus semakin menjanjikan bilamana terdapat suatu kombinasi yang menguntungkan antara produksi getah yang tinggi dan produksi kayu pada akhir daur yang tinggi juga.

Beberapa hasil penelitian menunjukkan bahwa produksi getah mempunyai hubungan (korelasi genetik) yang positif dengan pertumbuhan tanaman pinus (Woolaston et al., 1990; Pswarayi et al., 1996; Roberds et al., 2003; Sherrill et al., 2006; Xie \& Ying, 1996; Susilowati et al., 2013). Hubungan produksi getah dan pertumbuhan pinus yang positif memberikan pemahaman bahwa hasil akhir produksi getah tinggi juga akan menghasilkan produksi pertumbuhan (kayu) yang tinggi. Namun, beberapa hasil penelitian yang lainnya menunjukkan hasil yang berbeda, dimana produksi getah pinus justru mempunyai hubungan (korelasi genetik) yang negatif dengan pertumbuhan tanaman pinus (Leksono, 1994; Meier \& Goggans, 1978).

Atas dasar tersebut, penelitian ini dilakukan untuk mengetahui hubungan antara produksi getah dengan pertumbuhan tinggi dan diameter pada tanaman uji keturunan $P$. merkusii produksi getah di Kesatuan Pemangkuan Hutan (KPH) Banyumas Barat. Data dan informasi yang dihasilkan nantinya bisa digunakan sebagai bahan pertimbangan dalam pengembangan tanaman $P$. merkusii untuk produksi getah dan juga kayu yang tinggi.

\section{METODE PENELITIAN}

\section{A. Tempat dan Waktu}

Penelitian dilakukan bulan Agustus 2011 sampai Maret 2012 pada tanaman uji keturunan $P$. merkusii di Petak 37C Resort Pemangkuan Hutan (RPH) Samudra, Bagian Kesatuan Pemangkuan Hutan (BKPH) Lumbir, Kesatuan Pemangkuan Hutan (KPH) Banyumas Barat, Perhutani Unit I Jawa Tengah. Lokasi uji tersebut berada pada 
ketinggian 300-500 mdpl, rata-rata suhu harian $26,3^{\circ} \mathrm{C}$ (minimum $24,4^{\circ} \mathrm{C}$ dan maksimum $30,9^{\circ} \mathrm{C}$ ), rata-rata curah hujan $3.500 \mathrm{~mm} /$ tahun, termasuk tipe iklim B (Schmidt Fergusson), topografi bergelombang dan berbukit dengan kemiringan $30-45^{\circ}$ serta jenis tanah mediteran (alfisol) dari bahan induk batu kapur dan napal.

\section{B. Bahan dan Alat Penelitian}

Bahan yang digunakan dalam penelitian ini adalah tanaman uji keturunan $P$. merkusii yang dibangun pada tahun 2007. Tanaman uji menggunakan materi dari pohon induk hasil seleksi massa berdasarkan kriteria utama kemampuan pohon untuk menghasilkan getah yang tinggi (>50 $\mathrm{g} /$ pohon/3 hari), memiliki karakateristik pertumbuhan bagus (diameter relatif besar dan tinggi), batang relatif lurus serta tidak terserang hama dan penyakit. Uji keturunan tersebut dibangun untuk tujuan utama sebagai penghasil getah produksi tinggi (bocor getah) dengan sistem sub galur berdasarkan asal-usul pohon induk (Fakultas Kehutanan Universitas Gadjah Mada, 2006), menggunakan rancangan Incomplete Block Design (IBD) Row Column Design dengan jumlah famili, jumlah pohon per plot dan replikasi yang berbeda (Tabel 1).

Tabel 1. Materi genetik penelitian uji keturunan pinus di KPH Banyumas Barat Table 1. Genetic material of progeny test in KPH Banyumas Barat

\begin{tabular}{lccc}
\hline $\begin{array}{l}\text { Sub galur } \\
\text { (subline) }\end{array}$ & $\begin{array}{c}\text { Jumlah Famili } \\
\text { (number of } \\
\text { family) }\end{array}$ & $\begin{array}{c}\text { Jumlah pohon/plot } \\
\text { (number of tree/ } \\
\text { plot) }\end{array}$ & $\begin{array}{c}\text { Jumlah blok } \\
\text { (number of } \\
\text { replication) }\end{array}$ \\
\hline KBS Sumedang 1 & 50 & 3 & 10 \\
Sulawesi 1 & 40 & 4 & 5 \\
Sulawesi 2 & 44 & 4 & 7 \\
Jatim 2 & 40 & 4 & 7 \\
\hline & & $\pm 2-3 \mathrm{~cm}$ dari & permukaan kayu terluar \\
Peralatan yang digunakan adalah peta & sehingga &
\end{tabular}
penanaman uji keturunan P. merkusii, tally sheet untuk mencatat data hasil pengukuran, pita meter untuk mengukur diameter batang, galah ukur untuk mengukur tinggi tanaman, bor kayu, mata bor $10 \mathrm{~mm}$, kantong plastik, rafia, selang $10 \mathrm{~mm}$, alat tulis, dan timbangan digital.

\section{Tahapan Pelaksanaan/Rancangan Penelitian}

Pertumbuhan tinggi tanaman diukur mulai dari permukaan tanah sampai titik apikal tanaman, sedangkan diameter batang diukur pada posisi setinggi dada/dbh (130 cm dari permukaan tanah). Getah pinus dipanen dengan teknik pengeboran (mata bor $10 \mathrm{~mm}$ ) batang pada ketinggian $\pm 50 \mathrm{~cm}$ dari permukaan tanah dengan kemiringan $30^{\circ}-45^{\circ}$ mengarah poros batang ke atas. Kedalaman pengeboran lubang yang terbentuk masih berada pada lapisan kayu gubal. Pengeboran dilakukan di kanan dan kiri batang searah dengan kontur, dimana posisi yang satu kedudukannya lebih tinggi dari yang lain. Getah yang keluar dialirkan melalui selang yang pada bagian ujungnya diikat dengan kantong plastik untuk menampung getah. Pemanenan dilakukan pada hari ke-3 dan langsung dilakukan kegiatan penimbangan berat getah. Teknik pengeboran dan pemakaian kantong plastik untuk produksi getah umumnya dilakukan untuk kegiatan penelitian karena getah yang dihasilkan langsung tertampung dalam wadah plastik dan tidak terkontaminasi dengan kotoran dan air hujan (Danarto, 1999; Kurniawan, 2004), sehingga hasil getah yang di dapatkan merupakan getah murni. Selain itu, penyadapan dengan sistem bor 
menyebabkan sedikit kerusakan pada kulit dan jaringan kambium (Lekha, 2002).

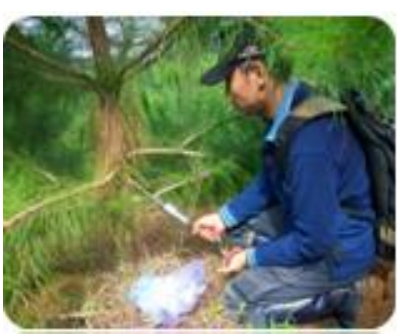

a

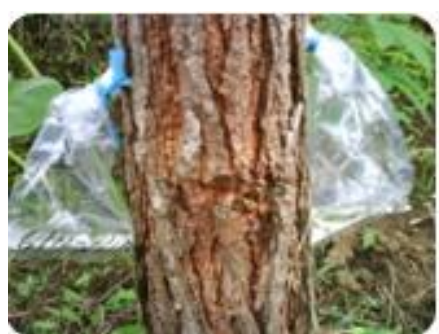

B

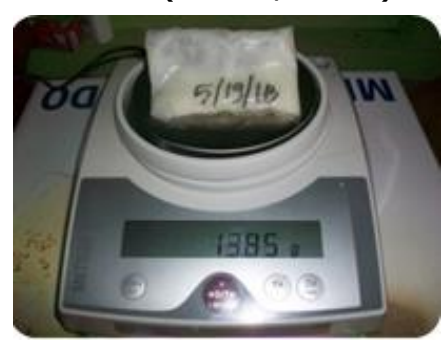

C

Gambar 1 . Sistem pengeboran untuk penyadapan getah (a), penampungan getah pada kantong plastik, (b) penimbangan getah (c)

Figure 1. Drill system for tapping resin (a), plastic bags for container resin (b), weighing of resin (c)

\section{Analisis Data}

Pengamatan dan pengukuran dilakukan pada semua pohon (sensus). Data yang diperoleh berupa variabel tinggi $(m)$, diameter $(\mathrm{cm})$ dan produksi getah yang merupakan rerata rata-rata produksi getah dari dua pengeboran batang (kanan dan kiri batang). Penghitungan taksiran komponen varians dan kovarians dihitung menggunakan restricted maximum likelihood (REML) dengan model matematis yang digunakan adalah:

$Y_{i j k l m}=\mu+R_{m}+B_{j(m)}+K_{l(m)}+F_{i}+$ $\mathrm{RF}_{\mathrm{mi}}+\mathrm{E}_{\mathrm{ijk} k \mathrm{~m}}$

Keterangan:

$\mathrm{Y}_{\mathrm{ijk} k \mathrm{~m}}=$ pengamatan pada replikasi ke-m, famili ke-i, baris ke-j dan kolom ke-l (observation of the $m$-th replication, ith family, $j$-th row and i-th column)

$\mu \quad=$ rerata umum (fixed term overall mean)

$\mathrm{R}_{\mathrm{m}} \quad=$ replikasi ke-m (fixed effect of the $m$-th replication)

$B_{j(m)}=$ efek baris ke-j dalam replikasi ke-m (fixed effect of the $j$-th row in the $m$-th replication)

$\mathrm{K}_{\mathrm{I}(\mathrm{m})}=$ efek kolom ke-l dalam replikasi ke-m (fixed effect of the l-th column in the $m$-th replication)

$\mathrm{F}_{\mathrm{i}}=$ efek famili ke-i (random effect of the $i$ th family)

$\mathrm{RF}_{\mathrm{mi}}=$ efek interaksi pada replikasi ke-m dan famili ke-i (random effect of the interaction between the $m$-th replication and $i$-th family)

$\mathrm{E}_{\mathrm{ijk} \mathrm{km}}=$ random galat pada pengamatan keijklm (random error of the observation ijk/mn-th)
Korelasi genetik antara tinggi dan diameter terhadap produksi getah dihitung dengan menggunakan rumus (Zobel \& Talbert, 1984):

$\mathrm{rG}=\frac{\sigma f(x y)}{\sqrt{ }\left(\sigma^{2} f(x) \cdot \sigma^{2} f(y)\right)} \quad$ Dimana, of $(x y)=0,5\left(\sigma^{2} f(x+y)-\sigma^{2} f(x)-\sigma^{2} f(y)\right)$

Keterangan:

rG : korelasi genetik (genetic correlation)

of (xy) : komponen kovarians untuk sifat $\mathrm{x} d n$ $y$ (covariance component for $x$ and $y$ traits)

$\sigma^{2} f(x) \quad$ : komponen varians untuk sifat $x$ (variance component for $x$ trait)

$\sigma^{2} f(y) \quad$ : komponen varians untuk sifat $y$ (variance component for $y$ trait)

$\sigma^{2} f(x+y)$ : komponen varians untuk sifat $x$ dan $y$ (variance component for $x$ and $y$ traits)

Sedangkan korelasi fenotipik dihitung dengan menggunakan rumus (Hardiyanto, 2008) :

$$
r p=\frac{\sigma p(x y)}{\sigma p_{(x)} \cdot \sigma p_{(y)}}
$$

Keterangan:

rp : korelasi fenotipik (phenothipic correlation)

$\sigma p(x y)$ : komponen kovarians fenotipik untuk sifat $x$ dan y (covariance component of phenothipic for $x$ and $y$ trait.

$\sigma p(x)$ : komponen kovarians fenotipik untuk sifat $x$ (covariance component of phenothipic for $x$ traits)

$\sigma p(y)$ : komponen kovarians fenotipik untuk sifat y (covariance component of phenothipic for $y$ traits) 


\section{HASIL DAN PEMBAHASAN}

Pertumbuhan tanaman uji keturunan pinus produksi getah di KPH Banyumas Barat pada umur 4 tahun (Tabel 2) mempunyai rerata tinggi $4,37 \pm 0,11 \mathrm{~m}$, pertumbuhan tinggi terbesar dari sub galur KBS Sumedang $(4,53 \pm 1,03 \mathrm{~m})$ dan terendah dari sub galur Sulawesi 1 $(4,22 \pm 0,95 \mathrm{~m})$. Rata-rata pertumbuhan diameter adalah 6,27+1,89 cm pertumbuhan diameter terbesar dari sub galur Sulawesi $2(6,68 \pm 1,94 \mathrm{~cm})$ dan terendah dari sub galur Sulawesi 1 $(5,33 \pm 1,66 \mathrm{~cm})$. Produksi getah mempunyai

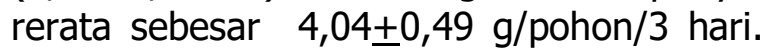
Produksi getah tertinggi terdapat pada sub galur KBS Sumedang $(4,58 \pm 0,27 \mathrm{~g} /$ pohon/3 hari) dan terendah pada sub galur Sulawesi $2(3,50 \pm 0,18 \mathrm{~g} /$ pohon $/ 3$ hari).

Tabel 2. Rerata pertumbuhan tinggi, diameter dan produksi getah tanaman uji keturunan P. merkusii umur 4 tahun di KPH Banyumas Barat

Table 2. Average of height, diameter and resin yield of the 4 years old $\underline{P}$. merkusii progeny test in KPH Banyumas Barat

\begin{tabular}{lccc}
\hline & \multicolumn{3}{c}{ Rerata Umum (Average) } \\
\cline { 2 - 4 } \multicolumn{1}{c}{$\begin{array}{c}\text { Sub Galur } \\
\text { (subline) }\end{array}$} & $\begin{array}{c}\text { Tinggi (height) } \\
(\mathrm{m})\end{array}$ & $\begin{array}{c}\text { Diameter } \\
\text { (diameter) } \\
(\mathrm{cm})\end{array}$ & $\begin{array}{c}\text { Produksi Getah } \\
\text { (g/pohon/3 hari) } \\
\text { (resin yield) }(\mathrm{g} / \text { tree) } \\
\text { 3 day) }\end{array}$ \\
\hline Jatim 2 & $4,41 \pm 1,08$ & $6,61 \pm 1,98$ & $4,45 \pm 0,25$ \\
Sulawesi 1 & $4,22 \pm 0,95$ & $5,33 \pm 1,66$ & $3,57 \pm 0,21$ \\
Sulawesi 2 & $4,37 \pm 0,99$ & $6,68 \pm 1,94$ & $3,50 \pm 0,18$ \\
KBS Sumedang & $4,53 \pm 1,03$ & $6,67 \pm 1,99$ & $4,58 \pm 0,27$ \\
Rerata (average) & $4,37 \pm 0,11$ & $6,27 \pm 1,89$ & $4,04 \pm 0,49$ \\
\hline
\end{tabular}

Persentase komponen varians famili $\left(\sigma^{2} f\right)$ (Tabel 3 ) produksi getah mempunyai rerata yang relatif kecil yaitu sebesar $8,27 \%$, di lain pihak rerata persentase komponen varian interaksi replikasi dengan family mempunyai nilai yang lebih besar yaitu $13,74 \%$. Hal ini mengindikasikan bahwa produksi getah tidak hanya dipengaruhi oleh genetik semata, namun juga terdapat hubungan interaksi antara genetik dan lingkungan yang juga mempengaruhi produksi getah.

Tabel 3. Taksiran komponen varian (tkv) produksi getah dari masing-masing sumber variasi dan persentasenya terhadap varian total

Table 3. Variance component estimation of resin production and the percentage of total variance

\begin{tabular}{|c|c|c|c|c|c|c|c|c|}
\hline \multirow{2}{*}{$\begin{array}{c}\text { Sumber variasi } \\
\text { (source of variation) }\end{array}$} & \multicolumn{2}{|c|}{$\begin{array}{c}\text { KBS } \\
\text { Sumedang } 1\end{array}$} & \multicolumn{2}{|c|}{$\begin{array}{c}\text { Sulawesi } \\
1 \\
\end{array}$} & \multicolumn{2}{|c|}{$\begin{array}{c}\text { Sulawesi } \\
2 \\
\end{array}$} & \multicolumn{2}{|c|}{ Jatim 2} \\
\hline & Tkv & (\%) & tkv & (\%) & tkv & (\%) & tkv & (\%) \\
\hline Replikasi (replication) & 0,017 & 6,32 & 0,01 & 6,28 & 0,02 & 10,76 & 0,011 & 4,36 \\
\hline Baris(rep.) (row(repl.)) & 0,000 & 0,00 & 0,00 & 1,35 & 0,01 & 5,33 & 0,005 & 2,14 \\
\hline Kolom(rep.) (col(repl.)) & 0,007 & 2,64 & 0,02 & 6,73 & 0,00 & 0,00 & 0,000 & 0,00 \\
\hline Famili (family) & 0,024 & 8,92 & 0,02 & 9,87 & 0,01 & 7,53 & 0,017 & 6,74 \\
\hline Rep.*Fam. (repl.*family) & 0,056 & 20,81 & 0,03 & 13,45 & 0,01 & 6,46 & 0,036 & 14,26 \\
\hline Galat (error) & 0,165 & 61,32 & 0,14 & 62,33 & 0,13 & 69,93 & 0,183 & 72,50 \\
\hline
\end{tabular}

Keterangan: $\mathrm{tkv}=$ taksiran komponen varians

Remark: $t k v=$ variance component estimation 
Persentase komponen varians famili $\left(\sigma^{2} f\right)$ sebagaimana ditunjukkan pada Tabel 4 dan 5 pertumbuhan tinggi dan diameter mempunyai rerata yang relatif kecil yaitu berturut-turut sebesar $5,63 \%$ dan $4,23 \%$. Hal ini mengindikasikan bahwa sampai dengan umur empat tahun, pertumbuhan tinggi dan diameter pinus lebih dipengaruhi oleh faktor lingkungan dibandingkan faktor genetik. Xie and Ying (1996) mengemukakan bahwa persentase taksiran komponen varians famili $\left(\sigma^{2} f\right)$ pada tanaman $P$. contorta untuk pertumbuhan tinggi pada umur 7, 10, 14, 19 dan 24 tahun berturut-turut sebesar $7,73 \%$, 5,81\%, 5,85\%, 5,46\%, 4,75\%; sedangkan pada pertumbuhan diameter pada umur 14 , 19 dan 24 tahun berturut-turut adalah sebesar $5,08 \%, 5,31 \%$ dan $6,06 \%$.

Pada Tabel 6 terlihat bahwa koefisien korelasi genetik dan korelasi fenotipe mempunyai nilai yang berbeda. Hal ini mengindikasikan bahwa korelasi fenotipe yang ada tidak sepenuhnya merupakan ekspresi dari genetik, dimana faktor lingkungan dan interaksi antara faktor lingkungan dan genetik akan banyak berpengaruh terhadap penampilan fenotipe tanaman yang sekaligus akan berpengaruh terhadap nilai korelasi fenotipe.

Korelasi genetik antara pertumbuhan tinggi dan diameter pada sub galur Sumedang, Sulawesi 2 dan Jatim 2 mempunyai nilai yang tinggi dan positif, hal ini mengindikasikan bahwa peningkatan pertumbuhan tinggi juga akan meningkatkan pertumbuhan diameter tanaman. Korelasi genetik antara pertumbuhan tinggi dan diameter yang tinggi juga terdapat pada beberapa penelitian tanaman pinus lainnya. Woolaston et al. (1990) mengemukakan bahwa korelasi genetik antara tinggi dan diameter tanaman $P$. caribaea pada umur 4,7 tahun dan 7,3 tahun di Australia sebesar 0,81 dan 0,57 . Korelasi genetik tinggi dan diameter $P$. elliottii umur 5, 8 dan 15 tahun di Zimbabwe berturut-turut sebesar 0,80; 0,78 dan 0,75 (Pswarayi et al., 1996). Korelasi genetik tinggi dan diameter $P$. taeda di Florida pada umur 11 tahun sebesar 0,89 (Roberds et al., 2003) dan pada umur 13 tahun di Amerika sebesar 0,77 (Sherrill et al., 2006). Korelasi genetik pada tanaman $P$. contorta umur 14, 19 dan 24 tahun di Kolumbia berturut-turut sebesar 0,63; 0,68 dan 0,61 (Xie \& Ying, 1996), pada $P$. massoniana umur 8 tahun di FujianChina adalah sebesar 0,83 (Liu et al., 2012), pada $P$. caribaea umur 15 tahun di Brazil sebesar 0,58 (Sebbenn et al., 2006), sedangkan pada $P$. taeda umur 7 tahun di Amerika (Georgia \& Florida) adalah 0,82 (Westbrook et al., 2013).

Korelasi genetik pertumbuhan tinggi dan diameter yang patut diperhatikan adalah pada sub galur Sulawesi 1 dengan nilai koefisien korelasi genetik yang berada di luar nilai yang semestinya atau lebih dari 1 atau -1 (over estimate) yaitu bernilai 1,50. Nilai yang over estimate ini sebenarnya juga terjadi pada beberapa penelitian lain pada variabel pengamatan yang berbeda-beda. Beberapa di antaranya yaitu koefisien korelasi genetik antara tinggi dan diameter tanaman uji klon Salix eriocephala sebesar 1,319 (Lin \& Zsuffa, 1993), korelasi genetik antara waktu inisiasi berbunga dan serangan penggerek batang pada tanaman uji keturunan Black locust (Robinia pseudocacia) sebesar 1,19 (Mebrahtu and Hanover, 1989), korelasi genetik antara tinggi tanaman dengan persentase tekanan kayu pada tanaman uji keturunan $P$. caribaea sebesar 2,05 (Harding et al., 1991), korelasi genetik tanaman $P$. caribaea antara sudut percabangan dengan tinggi dan diameter sebesar $-1,11$ dan 1,40 serta antara sudut percabangan dengan diameter cabang sebesar 1,05 (Ledig \& Whitmore, 1981).

Nilai koefisien korelasi genetik yang over estimate ini sebenarnya merupakan bagian dari konsekuensi rendahnya estimasi nilai heritabilitas karakter yang bersangkutan (Ledig \& Whitmore, 1981; Lin \& Zsuffa, 1993). Hal ini biasanya secara umum mempunyai nilai standar deviasi yang sangat besar dan nilai koefisien korelasi dengan faktor lingkungan yang sangat besar (Lin \& Zsuffa, 1993). Rendahnya nilai heritabilitas ini mungkin 
disebabkan oleh belum optimalnya kendali genetik sebagai pengaruh dari bentuk lahan dengan variasi yang tinggi. Hal ini menyebabkan taksiran persentase komponen ragam famili yang berada di bawah kendali genetik untuk pertumbuhan diameter menjadi sangat kecil $(3,45 \%)$ (Tabel 5). Di lain pihak, taksiran komponen ragam interaksi genetik dengan lingkungan (rep*famili) baik untuk pertumbuhan tinggi dan diameter menjadi sangat besar yaitu 44,90\% dan 52,47\% (Tabel 4 dan Tabel 5).

Tabel 4. Taksiran komponen varians (tkv) pertumbuhan tinggi dari masing-masing sumber variasi dan persentasenya terhadap varians total

Table 4. Variance component estimation of height growth and the percentage of total variance

\begin{tabular}{lrrrrrrrr}
\hline \multirow{2}{*}{$\begin{array}{c}\text { Sumber variasi } \\
\text { (source of variation) }\end{array}$} & \multicolumn{2}{c}{ KBS } & \multicolumn{2}{c}{ Sulawesi } & \multicolumn{2}{c}{ Sulawesi } & \multicolumn{2}{c}{ Jatim 2 } \\
\cline { 2 - 9 } & \multicolumn{1}{c}{ Sumedang 1 } & \multicolumn{1}{c}{ tkv } & \multicolumn{1}{c}{ Tkv } & \multicolumn{1}{c}{ (\%) } & \multicolumn{1}{c}{ Tkv } & \multicolumn{1}{c}{$(\%)$} & \multicolumn{1}{c}{ Tkv } & $(\%)$ \\
\hline Replikasi (replication) & 0,03 & 2,68 & 0,17 & 17,00 & 0,01 & 0,92 & 0,08 & 6,67 \\
$\quad$ Baris(rep.) (row(repl.)) & 0,01 & 1,11 & 0,05 & 5,00 & 0,00 & 0,00 & 0,09 & 7,50 \\
Kolom(rep.) (col(repl.)) & 0,12 & 11,10 & 0,05 & 5,00 & 0,01 & 0,95 & 0,06 & 5,00 \\
Famili (family) & 0,07 & 6,48 & 0,04 & 4,00 & 0,06 & 6,20 & 0,07 & 5,83 \\
Rep.*Fam. (repl.*family) & 0,23 & 21,28 & 0,25 & 25,00 & 0,42 & 44,90 & 0,20 & 16,67 \\
Galat (error) & 0,62 & 57,35 & 0,44 & 44,00 & 0,44 & 47,03 & 0,70 & 58,33 \\
\hline
\end{tabular}

Keterangan: $\mathrm{tkv}=$ taksiran komponen varians

Remark: tkv = variance component estimation

Tabel 5. Taksiran komponen varians (tkv) pertumbuhan diameter dari masing-masing sumber variasi dan persentasenya terhadap varians total

Table 5. Variance component estimation of diameter growth and the percentage of total variance

\begin{tabular}{|c|c|c|c|c|c|c|c|c|}
\hline \multirow{2}{*}{$\begin{array}{c}\text { Sumber variasi } \\
\text { (source of variation) }\end{array}$} & \multicolumn{2}{|c|}{$\begin{array}{c}\text { KBS } \\
\text { Sumedang } 1 \\
\end{array}$} & \multicolumn{2}{|c|}{$\begin{array}{c}\text { Sulawesi } \\
2 \\
\end{array}$} & \multicolumn{2}{|c|}{$\begin{array}{c}\text { Sulawesi } \\
1 \\
\end{array}$} & \multicolumn{2}{|c|}{ Jatim 2} \\
\hline & tkv & (\%) & Tkv & $(\%)$ & Tkv & $(\%)$ & Tkv & $(\%)$ \\
\hline Replikasi (replication) & 0,89 & 2,1 & 5,3 & 13,8 & 1,3 & 46 & 4,25 & 10,14 \\
\hline$w($ repl. $))$ & 0,11 & 0,27 & 2,92 & 7,57 & 0,34 & 1,21 & 2,18 & 5,20 \\
\hline Kolom(rep.) (col(repl.)) & 4,39 & 10,79 & 3,43 & 8,90 & 0,21 & 0,75 & 2,05 & 4,89 \\
\hline Famili (family) & 2,13 & 5,23 & 1,17 & 3,03 & 0,97 & 3,45 & 2,34 & 5,58 \\
\hline Rep.*Fam. (repl.*family) & 15,62 & 38,38 & 11,72 & 30,39 & 14,75 & 52,47 & 15,93 & 37,99 \\
\hline Galat (error) & 17,56 & 43,14 & 13,99 & 36,28 & 10,53 & 37,46 & 15,18 & 36,20 \\
\hline
\end{tabular}

Keterangan: $\mathrm{tkv}=$ taksiran komponen varians

Remark: $t k v$ = variance component estimation

Korelasi genetik antara produksi getah dengan tinggi pada sub galur KBS Sumedang bernilai sangat rendah. Dapat dikatakan bahwa produksi getah secara genetik tidak dipengaruhi pertumbuhan tinggi tanaman. Namun, korelasi genetik pertumbuhan diameter dengan produksi getah bernilai sedang dan negatif. Artinya bahwa semakin tinggi produksi getah pinus maka diameter pohon cenderung semakin kecil. Beberapa penelitian lain juga mempunyai hasil yang serupa. Korelasi genetik produksi getah dengan diameter $P$. merkusii umur 12 tahun sebesar -0,37 sampai dengan -0,07 (Leksono, 1994), sedangkan korelasi genetik produksi monoterpene dengan tinggi dan diameter $P$. virginiana umur 8 tahun sebesar -0,03 dan 0,13 (Meier \& Goggans, 1978). 
Tabel 6. Korelasi genetik (rG) dan fenotipe tanaman uji keturunan $P$. merkusii di $\mathrm{KPH}$ Banyumas Barat

Table 6. Genetic (rg) and phenotypic correlation of P. merkusii progeny test in KPH Banyumas Barat

\begin{tabular}{|c|c|c|c|}
\hline \multirow{2}{*}{$\begin{array}{l}\text { Sub Galur } \\
\text { (subline) }\end{array}$} & \multirow{2}{*}{$\begin{array}{l}\text { Korelasi } \\
\text { (correlation) }\end{array}$} & \multicolumn{2}{|c|}{$\begin{array}{c}\text { Koefisien korelasi } \\
\text { (coefficient of correlation) }\end{array}$} \\
\hline & & $\begin{array}{l}\text { Genetik } \\
\text { (genetic) }\end{array}$ & $\begin{array}{c}\text { Fenotipe } \\
\text { (phenotypic) }\end{array}$ \\
\hline \multirow[t]{3}{*}{ KBS Sumedang } & Tinggi-diameter & 0,62 & 0,81 \\
\hline & Prod. getah-Tinggi & $-0,07$ & 0,34 \\
\hline & Prod. getah-Diameter & $-0,59$ & 0,36 \\
\hline \multirow[t]{3}{*}{ Sulawesi 2} & Tinggi-diameter & 0,90 & 0,84 \\
\hline & Prod. getah-Tinggi & 0,50 & 0,37 \\
\hline & Prod. getah-Diameter & 0,83 & 0,34 \\
\hline \multirow[t]{3}{*}{ Sulawesi 1} & Tinggi-diameter & 1,50 & 0,83 \\
\hline & Prod. getah-Tinggi & 0,62 & 0,31 \\
\hline & Prod. getah-Diameter & 0,86 & 0,39 \\
\hline \multirow[t]{3}{*}{ Jatim 2} & Tinggi-diameter & 0,75 & 0,81 \\
\hline & Prod. getah-Tinggi & 0,33 & 0,35 \\
\hline & Prod. getah-Diameter & 0,56 & 0,40 \\
\hline
\end{tabular}

Pada sub galur Sulawesi 1 , Sulawesi 2 dan sub galur Jatim 2, korelasi genetik antara produksi getah dengan tinggi mempunyai koefisien korelasi sebesar 0,330,62 (rendah sampai sedang) dan korelasi genetik produksi getah dengan diameter sebesar 0,56-0,86 (sedang sampai tinggi). Korelasi genetik yang besar dan positif mengindikasikan bahwa semakin tinggi pertumbuhan tinggi dan diameter pohon maka semakin besar pula produksi getah. Beberapa penelitian lain juga mengemukakan korelasi genetik yang bernilai positif. Roberds et al. (2003) mengemukakan bahwa korelasi genetik produksi getah dengan tinggi dan diameter $P$. taeda umur 10 tahun sebesar 0,67 dan 0,58 , sedangkan korelasi genetik produksi getah dengan tinggi dan diameter tanaman full sib P. elliottii pada umur 15 tahun sebesar 0,24 dan 0,10 (Pswarayi et al., 1996). Korelasi genetik antara diameter dengan produksi getah dan tinggi pohon dengan produksi getah pada tanaman $P$. massoniana pada umur 8 tahun adalah sebesar 0,73 dan 0,47 (Liu et al., 2012). Korelasi genetik antara tinggi dan diameter dengan berat kering getah pada $P$. taeda umur 7 tahun adalah sebesar 0,39 dan 0,26 (Westbrook et al., 2013)

Hasil penelitian ini dan beberapa penelitian lainnya menunjukkan bahwa secara umum korelasi genetik produksi getah dengan tinggi dan diameter pohon mempunyai nilai yang "tidak konsisten" dalam pengertian nilainya tidak menunjukkan kecenderungan pola yang sama. Shimizu \& Spir (1999) mengemukakan bahwa pada plot uji keturunan $P$. eliottii umur 11 tahun, variasi genetik antar famili untuk variabel tinggi dan diameter mempunyai nilai yang berbeda tidak nyata, namun produksi getah berbeda nyata antar famili. $\mathrm{Hal}$ ini mengindikasikan bahwa sebenarnya faktor produksi getah tidak mutlak ditentukan oleh faktor pertumbuhan, khususnya tinggi dan diameter saja, tetapi terdapat faktor lain yang bekerja lebih spesifik yang bisa mempengaruhi produksi getah secara langsung. 


\section{KESIMPULAN DAN SARAN}

\section{A. Kesimpulan}

Plot uji keturunan pinus produksi getah di $\mathrm{KPH}$ Banyumas Barat yang dibangun dengan tujuan utama untuk produksi getah tinggi, mempunyai nilai korelasi genetik antara produksi getah dengan pertumbuhan tinggi dan diameter yang berbeda-beda. Korelasi genetik bernilai positif pada sub galur Sulawesi 1 , Sulawesi 2 dan Jatim 2; sedangkan korelasi bernilai negatif pada sub galur KBS Sumedang.

\section{B. Saran}

Korelasi genetik antara produksi getah dengan pertumbuhan pada sub galur Sulawesi 1, Sulawesi 2 dan Jatim 2 bernilai positif, maka pada sub galur tersebut bisa digunakan untuk pengembangan tanaman yang menghasilkan produksi getah dan kayu. Sedangkan untuk sub galur KBS Sumedang mempunyai korelasi produksi getah dengan variabel pertumbuhan yang bernilai negatif, sehingga sub galur KBS Sumedang lebih diutamakan untuk tujuan produksi getah.

\section{UCAPAN TERIMA KASIH}

Penulis mengucapkan terima kasih kepada Prof. Dr. Ir. Moh. Na'iem M. Agr, Sc dan Dr. Ir. Eko Bhakti Hardiyanto, M.Sc atas perbaikan, saran dan masukannya. Tim pemuliaan pohon Universitas Gadjah Mada (Purwanto, Titis Hutama Syah), dan tim pemuliaan pohon Perhutani (Sugi Purwanta, Carso, Rata-roto).

\section{DAFTAR PUSTAKA}

Antara. (2010). Perhutani Bidik 20-22 Juta Dolar dari Gondorukem. http://www.seputarforex.com/berita/e konomi/. Diakses tanggal 27 Juli 2010.

Danarto, S. (1999). Penentuan Pohon Plus, Pengunduhan Buah, Pendataan Potensi Getah dan Pemapanan Tanaman Uji Keturunan Benih Jawa. Laporan Hasil Eksplorasi Tusam di
Sulawesi Selatan. Kerjasama Fakultas Kehutanan UGM dan Perum Perhutani. Tidak dipublikasikan.

Fakultas Kehutanan UGM. (2006). Laporan Penelitian Pinus Bocor Getah No. 04/ SJ/ PBC/ 2006. Kerjasama Pusat Penelitian dan Pengembangan Perhutani Cepu dan Fakultas Kehutanan Universitas Gadjah Mada. Yogyakarta. Tidak dipublikasikan.

Harding, K. J., P. J. Kanowski and R. R. Woolaston. (1991). Preliminary genetic parameter estimates for some wood quality traits of Pinus caribaea var. hondurensis in Queensland, Australia. Silva Genetica 40: 152-156.

Hardiyanto, E. B. (2008). Diktat Mata Kuliah Pemuliaan Pohon Lanjut. Program Pasca Sarjana. Fakultas Kehutanan Universitas Gadjah Mada Yogyakarta. Tidak dipublikasikan

Hasniawati, A. P. (2010). Bisnis Pengolahan Getah Pinus. http://www.indonesiahijau.com/bisnis-pengolahan-getahpinus.php. Diakses tanggal 25 Juli 2011.

Kementerian Keuangan. (2012). Keputusan Menteri Keuangan Republik Indonesia No: $\quad 1956 / K M .4 / 2012$ tentang Penetapan Harga Ekspor Untuk Penghitungan Bea Keluar.http://repository.beacukai.go.id /peraturan/2012/06/51b58d788cfb72a $4 f a 62$ de1df291b322-1956km4_2012.pdf. Diakses tanggal 19 Oktober 2012.

Kurniawan, T. (2004). Deteksi Awal Potensi Getah Pohon-Pohon Elit di Kebun Benih Semai Pinus merkusii Sempolan-Jember. Skripsi Mahasiswa Fakultas Kehutanan UGM. Yogyakarta. tidak dipublikasikan.

Ledig, F. T. and J.L. Whitmore. (1981). Heritability and Genetic Correlations for Volume, Foxtails, and other characteristics of Caribbean pine in Puerto Rico. Silvae Genetica 30, 2-3.

Leksono, B. (1994). Variasi Genetik Produksi Getah Pinus merkusii Jungh et de 
Vriese. Tesis Mahasiswa Fakultas Kehutanan UGM. Yogyakarta. Tidak dipublikasikan.

Lekha, C. (2002). Standardization of Borehole Method of Oleoresin Tapping in Chir Pine (Pinus roxburghii Sargent) Thesis College of Forestry. Dr. Yashwant Singh Parmar University of Horticulture and Forestry, Nauni, Solan. India. Unpublished.

Lin, J. Z. and L. Zsuffa. (1993). Quantitative Genetic Parameters for Seven Characters in a Clonal Test of Salix eriocephala, II. Genetic and Environmental Correlations and Efficiency of Indirect Selection. Silvae Genetica 42, 2-3.

Liu, B. Q., Z. Zhou, H. Fan and Y. Liu. (2013). Genetic Variation and Correlation among Resin Yield, Growth, and Morphologic Traits of Pinus massoniana. Silvae Genetica 62, 1-2.

Mebrahtu, T. and J. W. Hanover. (1989). Heritability and expected gain estimates for traits of black locust in Michigan. Silvae Genetica. 38: 125130.

Meier R. J. and J.F. Goggans. (1978). Heritability and Correlation of The Cortical Monoterpene of Virginia Pine (Pinus virginiana Mill). Silvae Genetica 27, 2 : 79-84.

Prasetia, R. Y. (2008). Potensi Getah Pertanaman Uji Keturunan Pinus merkusii Jungh. et de Vriese Materi Introduksi Genetik Asal Aceh di RPH Sumberjati, BKPH Sempolan, KPH Jember. Skripsi Mahasiswa Jurusan Budidaya Hutan. Fakultas Kehutanan UGM. Yogyakarta. Tidak dipublikasikan.

Pswarayi, I. Z., R. D. Barnes, J. S. Birks and P. J. Kanowski. (1996). Genetic Parameters Estimates for Production and Quality Traits of Pinus elliottii Engelm. var. elliottii in Zimbabwe. Silvae Genetica 45, 4.
Roberds, J. H., B. L. Strom, F. P. Hain, D. P. Gwaze, S. E. McKeand and L. H. Lott. (2003). Estimates of genetic parameters for oleoresin and growth traits in juvenile loblolly pine. Can. J. For. Res. 33: 2469-2476.

Saepudin, A. (2010). Arti Tetesan Getah Pinus. Majalah DADALI edisi bulan Oktober 2010.

Sherrill, J. R., T. J. Mullin, B. P. Bullock, S. E. McKeand, R. C. Purnell, M. L. Gumpertz and F. Isik. (2008). An Evaluation of Selection for Volume Growth in Loblolly Pine. Silvae Genetica 57, 1.

Shimizu, J, Y., and I. H. Z. Spir. (1999). Selecão De Pinus Elliottii Pelo Valor Genético Para Alta Produção De Resina (Selection of Slash Pine on Breeding Values for High Resin Production). Boletim de Pesquisa Florestal, Colombo, n. 38, p. 103-117, Jan./Jun. Sebbenn, A. M., F. C. Arantes, O. V. Boas and M. L. M. Freintas. (2008). Genetic Variation in an International Provenance-Progeny Test of Pinus caribaea Mor. var. bahamensis Bar. et Gol., In Sao Paulo, Brazil. Silvae Genetica 57, 4-5.

Susilowati, A., I. Z. Siregar, Supriyanto, I. Wahyudi, Corryanti. (2013). Genetic Variation, Heritability and Correlation Between Resin Production Character of Pinus merkusii High Resin Yielder (Hry). Biotropia Vol. 20 No. 2, 2013:122-133. DOI. 10.11598/btb.2013.20.2.1.

Woolaston, R.R., P. J. Kanowski and D. G. Nikles. (1990). Genetic Parameter Estimates for Pinus caribaea var. hondurensis in Coastal Quensland, Australia. Silvae Genetica 39, 1.

Westbrook, J. W., M. F. R. Resende Jr, P. Munoz, A. R. Walker, J. L. Wegrzyn, C. D. Nelson, D. B. Nale, M. Kirst, D. A. Huber, S. A. Gezan, G. F. Peter and J. M. Davis. (2013). Association genetics of oleoresin flow in loblolly pine: discovering genes and predicting 
phenotype for improved resistance to bark beetles and bioenergy potential. New Phytologist (2013) 199:89-100. DOI: $10.1111 / \mathrm{nph} .12240$.

Xie, C. Y. and C. C. Ying. (1996). Heritabilities, Age-Age Correlations, and Early Selection in Lodgepole Pine (Pinus contorta ssp. Latifolia). Silvae Genetica 45, 2-3.

Zobel, B.J. and J. T. Talbert. (1984). Appplied Forest Tree Improvement. John Willey and Sons. Inc. New York. 